\title{
Why Ireland and Irish Studies in South America?
}

\author{
Laura P. Z. Izarra \\ Universidade de São Paulo, Brazil
}

Copyright (c) 2021 by Laura P. Z. Izarra. This text may be archived and redistributed both in electronic form and in hard copy, provided that the author and journal are properly cited and no fee is charged for access.

When Declan Kiberd rightly asks "who invented Ireland?" in the introduction of his renowned Inventing Ireland (1995), he points out three possibilities: the Irish themselves, embodied in the words Sinn Féin (ourselves alone) which refer to the movement for national independence; the English fictional construction in response to a specific moment in British history, whose way of thinking was challenged by the 1916 insurrection; and, the massive emigration of hundreds of thousands of Irish men and women after the famines of the 1840s, "going to Britain, North America and Australia dreaming of a homeland, and committed to carrying a burden which few enough on native grounds still bothered to shoulder: an idea of Ireland" (2). Though the Irish in South America have not been in the scope ${ }^{1}$ of Irish historians and critics until the first decade of this century, Latin American scholars have been examining the Irish presence in their region since the early twentieth century, and these results should be inscribed in the global Irish agenda.

And, why has Ireland been the focus of non-English speaking countries across the Atlantic? Works of art are products of their age and Kiberd (1995) affirms that "certain masterpieces float free of their enabling conditions to make their home in the world" (4). Irish writers have been part of the syllabus of English Literature in the educational system worldwide and it was the Irish Renaissance led by W.B. Yeats and the legacy left by his generation, together with the history of Irish emigration to their lands, that awoke the interest of South Americans. If artworks have always been notable for their engagement with society and "for [their] prophetic reading of the forces at work in their time" (ibid. ibidem), people from these South American countries read Irish authors because they share a similar past of colonial experience and still live the painful process of emerging nation-states.

Although the wars of Independence in South America occurred in the first half of the nineteenth century -a century before the Irish Independence- some Irish immigrants and their descendants were revolutionary leaders in the struggles against the dominant power of Spain. ${ }^{2}$ For instance, William Bulfin was an Irish diasporic writer who lived in Argentina for 22 years and was the editor of the Irish community's newspaper The Southern Cross from 1896 to 1906 (still being printed today), who ironically complains in his book Rambles in Eireen (1907) that these Irish heroes should be in Ireland fighting for their own independence: "Glory of the Irish in exile! [...] Of what good is it all to Ireland? The battle for Ireland must be fought in Ireland, by the people of Ireland" (247). In tandem with Kiberd's reasoning, the fact that a cultural revival came first and inspired the Irish political revolution that followed, the presence of a conscious national and artistic intensity in Irish artworks, and the 
nineteenth-century thousands of Irish men and women who helped shape modern Latin America have inspired Irish Studies at the crossroads of literature, history and culture in the west South Atlantic continent.

In this think-piece I will reflect upon Irish Studies from a Brazilian higher education viewpoint and in relation to border countries, as Brazil does not have a significant Irish immigration, neither in the past nor in the present. Settlement patterns were sporadic and more geographically concentrated in Argentina and the levels of a re-emigration to other destinations, such as Argentina, Australia or back to Ireland, were high. Since the mid-1500s Latin America has received various waves of Irish immigrants, members of Catholic families "displaced by colonial warfare at home" (Izarra and Rogers 2018). However, instead of writing a historiography of the Irish presence in these southern regions which has been the aim of other previous publications, I will question three main contemporary issues: what is the role of Irish Studies within the local educational system and its impact? What are the implications of this field of research within Humanities in the age of globalization? Which are the strategies for its consolidation in an institutional level?

\section{Irish Studies in Brazilian Higher Education}

In the last century, the aim of Latin American universities has been to improve the quality of learning and increase social inclusion in order to attend national and regional needs. More recently, their target has been to construct a Latin American knowledge network that could identify itself and interact with the hegemonic Western knowledge system. Ireland has become the centre of world interest in the twentieth and twenty-first centuries since its War of Independence was followed by the political consequences of its partition, the Civil War, the political instability and violence of the Troubles, and the transformation of the economy of the Republic from "the doom and gloom of the 1980s to the roaring tiger of the 1990s" (Keogh 411). This continues in the present, as Ireland is facing new challenges within the European Union due to the impact of Brexit on the Irish border.

From a parallel viewpoint, South America has also been under the world's gaze due to the political and economic instability of its countries: its wars of independence, the Amazon Rubber Boom (1879-1912) with denunciations of violence against the natives, the exploitation of natural resources of the Amazonian regions of Brazil and neighbouring countries, the extensive Irish immigrant community in Argentina that contributed to its development in the turn of the twentieth century, the internal guerrillas followed by coups and dictatorships in some of its countries, the Malvinas war, and in the last decades the mass emigration of a young generation to Ireland and Europe looking for better labour opportunities in their ancestors' homelands. In a mirror-like dynamics, South America is economically and politically the reverse of the coin as it experiences the devastating effects of subsequent crises of democracy. Social, historical and intellectual intersections and parallels exist in the political configurations of our times and motivate collaborative academic studies to create theoretical crossovers and to understand wider conjunctures within the global state of affairs.

Irish Studies in Brazil started in 1980s as the result of two doctoral theses, one on Sean O'Faolain's short stories by Prof. Munira Mutran at the University of São Paulo, and the other on the work of Samuel Beckett by her colleague Maria Helena Kopschitz at the Fluminense Federal University, in Rio de Janeiro. Both of them began a fruitful academic cooperation with University College Dublin and Queen's University Belfast, respectively, and received visiting professors on ad hoc basis at both Brazilian Institutions. ${ }^{3}$

Since the 1980s, MA dissertations and $\mathrm{PhD}$ theses on Irish literature have explored the work of various Irish writers of fiction, drama and poetry in the Postgraduate Programme at 
the University of São Paulo. Later, other paths have been trailed, such as Irish theatre, literature of the Irish diasporas; Irish-Latin American Migration Studies; Irish-Brazilian/IrishArgentinean historical and literary connections; Irish filmography and translation studies; the reception of Joyce and Shaw; a cartography of Irish immigration and Irish women in South America; the production of Irish theatre on the Brazilian stage; itinerary exhibitions and film festivals. Interdisciplinary and transdisciplinary research and comparative studies have opened up the field of Irish Studies. The Postgraduate Programme at the University of São Paulo has generated multipliers who are now professors at various universities in Brazil introducing their own students to this field of research.

Local research has brought into light Irish nineteenth-century diasporic writers, such as William Bulfin and Marion, Michael and Edward Mulhall in Argentina; William Scully, the editor of the Anglo-Brazilian Times in Brazil (1865-1884); references or traces of Irish authors in regional Latin American narratives and vice-versa, such as Borges and his interest in Irish writers, philosophers and culture ${ }^{4}$ and Anne Enright's novel on Eliza Lynch. There are also contemporary South American writers of Irish ascendancy or Irish writers who rewrite the immigrants' past, such as Rodolfo Walsh in the 1960s, Juan José Delaney since the 1970s, Susan Wilkinson since 1980s, Teresa Deane Reddy in the 1990s and Eduardo Cormick since the 1990s. A number of critical, literary and history books have been published since the beginning of the twentieth century. ${ }^{5}$ Literary manuscripts, relevant historical documents and nineteenth-century newspapers of the Irish community in Argentina and Brazil ${ }^{6}$ demand urgent digitization in order to be accessed and studied by a larger number of researchers who will complete the cartography of Irish Studies.

The founding of The Brazilian Association of Irish Studies (ABEI) in 1989, and the establishment of the W.B. Yeats Chair of Irish Studies at the University of São Paulo in 2009, with their respective publications, organization of events, courses and exhibitions not only in Brazil but also in Argentina and Chile, have helped to consolidate Irish Studies in Brazil and spread it to neighbouring countries when partner universities host the Symposium of Irish Studies in South America. Academic agreements of exchange promote joint-projects and publications, and the W. B. Yeats Chair receives Brazilian and foreign researchers with renewed interests that inspire connections with Ireland within the fields of humanities and technology. Thus, a bridge between Science and Arts is being constructed and scholarships for research and mobility of postgraduates and undergraduates were created by ABEI (ABEIHADDAD Foundation) and the Chair to provide them with the opportunity to develop their research in loco and to participate in IASIL Conferences and Irish University Summer Schools.

\section{Irish Studies in the Age of Globalization}

How can the results of research in Irish South American Studies become part of a world knowledge network in times of globalization when government policies and consequently, university policies, are not only reducing funding but also discrediting Humanities?

Being Brazil a large country, there is a great concern to keep Irish Studies scholars graduated from USP and other universities Postgraduate Programmes integrated. The thematic project "From Ireland to Brazil: Critical Texts" (2006-2009), funded by FAPESP (São Paulo State Research Funding Agency), was developed with the primary purpose of building a national knowledge network. This knowledge has been shared with specialists and the general public by means of extra-mural courses, the publication of books, the organisation of exhibitions and events, including the annual ABEI Symposium of Irish Studies in South America, and the yearly official opening of the W. B. Yeats Chair's activities. The various symposia have provided the opportunity for Brazilian scholars to interact with colleagues 
from bordering countries and with guest speakers from other European, Canadian and American Associations and Centres, such as AEDEI, IASIL, SILAS, CAIS, EFACIS, ACIS, AEIS, being the Society for Irish Latin American Studies (SILAS) and Asociación de Estudios Irlandeses del Sur (AEIS) our interlocutors since their founding. Agreements of exchange with some universities were signed within a growing institutional process of internationalisation. These double-edged border-crossing activities between national systems of higher education have built strong links between Irish partner universities and the University of São Paulo.

The first international joint project, "Las Américas e Irlanda: Estudios culturales y traducción" (2007-2014), took place with Universidad de La Pampa, in Argentina, as a result of the postgraduate courses I gave at that institution along those years. Prof. Maria Graciela Eliggi has introduced academic activities and events in Argentina inviting other leading universities to join their efforts and has founded the Association of Irish Studies of the South (AEIS) becoming its first president. Some books published by the W. B. Yeats Chair were translated into Spanish within that former project -for example, Roger Casement in South America (2012), the result of a collaborative work with the historian Angus Mitchell, which was published in Brazil in 2009.

The Chair also joined two challenging international networks led by Professor Jane Ohlmeyer from Trinity College Dublin: "SPeCTReSS - Social Performance, Cultural Trauma and the Reestablishing Solid Sovereignties" (2014-2017), funded by the European Commission, and "Crises of Democracy through the Prism of Cultural Trauma" (2018-2019), funded by US Mellon Foundation within the global network of the Consortium of Humanities Centers and Institutes (CHCI). ${ }^{7}$ SPeCTReSS was a transnational four-year programme of scholarly exchanges focusing on the concept of cultural trauma and national identities seen across different national and regional contexts to reveal how arts and culture represent societies undergoing deep traumatic stress. One of the core questions at the 18-month Crises of Democracy Global Humanities Institute (GHI) project was "what is it in the world today that is making populist and authoritarian approaches to government more attractive than democracy?" An open online syllabus ${ }^{8}$ and publications were the ways to share the knowledge and skills developed over the course of both projects and to disseminate the results in institutions and a wider society.

In "The Changing Debate of Internationalisation of Higher Education", Ulrich Teichler (2004) affirms that internationalisation "is losing ground to 'globalisation', increasing border-crossing activities of blurred national systems which is often employed to depict worldwide trends and growing global competition" (5). Global processes are shaped by the transformations of economy, goods and communication and, though they are fluid, the danger is that they could also be anonymous. In order to avoid this anonymity which could provoke a hegemonic knowledge power of unknown origin and interests, the human side of globalisation with its multifarious cultural dimension must be considered in the higher education agenda. The institutions participating in both multidimensional interdisciplinary networks aforementioned examine the drama of migrants and displaced peoples due to wars, hunger, dictatorships or labour diasporas; analyse the roots of historical and contemporary crises of democracy and try to identify the groups and causes that were responsible for the cultural traumas that "have created a rupture in the social fabric" (Eyerman 2011); and, focus their attention on those who produce, circulate and receive messages that provoke the reinvention of new ways of citizenship (Canclini 63-5).

The imaginary is a constituent of globalization and even though the positive aspect of the process of globalisation of higher education is a move towards global understanding, there are also various risks to be avoided. Thus, the internationalisation of the research agendas of institutions and of students' curricula should promote multilingualism and a multicultural 
interactive construction of global knowledge, as well as understanding, to avoid a homogeneous way of thinking that could colonize the minds of people. In addition, the multifaceted process of internationalization includes diversified interdisciplinary dimensions in search for higher quality and for constructing a dialogical complementary global agenda where discursive tensions fruitfully exist.

One example of a case study of Irish Studies in Brazil is a transnational research that started locally in the 1990s when I was researching the Irish emigration to South America, which evolved to become part of academic international networks. Roger Casement, one of the sixteen revolutionaries of the Easter Rising, was British consul in São Paulo (1906), Belém do Pará (1907) and Rio de Janeiro (1908); his presence was kept invisible in the global agenda and his actions have not been registered in the history of Brazil. The impact of his reports has been silenced for a long time in Ireland after his execution, until The Amazon Journal of Roger Casement (1997) as well as Sir Roger Casement's Heart of Darkness: The 1911 Documents (2003) were edited and published by the historian Angus Mitchell. Thus, joining common interests with Mitchell and at that time a doctoral student Mariana Bolfarine (now postdoctoral lecturer and W. B. Yeats Chair's associate researcher), a larger project was designed and hosted by the Chair at USP. In 2010, a conference in Manaus and a series of Seminars in São Paulo in 2011 were organized with the simultaneous launch of the itinerant exhibition and catalogue Roger Casement in Brazil (2010), published in English and then translated into Portuguese by Bolfarine and into Spanish by Eliggi, to commemorate the centenary of Casement's journeys to South America when he witnessed and denounced the violence perpetrated against the indigenous people in the Amazon and revealed the satanic participation of British capital in the subjugation of the natives during rubber extraction.

As followed, events and the launch of the first translation into Portuguese of The Amazon Journal by Roger Casement (co-edited with Bolfarine) were organized for the centenary of the Easter Rising. Since 2010, the itinerant exhibition has been launched in Madrid in 2012 at CasAmérica with the presence of Nobel Laureate for Literature Mario Vargas Llosa, in Barcelona (2013), Ireland (Tralee, 2013), Maputo (Mozambique, 2014), Davis University (California, 2016), Lima (Peru, 2017) with the presence of President Michael D. Higgins, and in various cities of Brazil and Argentina along these ten years. In 2020, the Brazilian filmmaker Aurélio Michiles finished a joint project with the Chair, a documentary based on Casement's journal, Secrets from Putumayo, with Stephen Rea as the voice of Roger Casement and interviews with Angus Mitchel, Brazilian writer Milton Hatoum and indigenous leaders of the region. In this way, the transnational research helped to retrieve Casement into the global history of human rights and the impact of his actions is now inscribed on the global Irish agenda. Moreover, the present situation of the region that has lately called the attention of the global media can be widely and better understood from different transnational and global economic and geopolitical perspectives within the Atlantic world context.

The process of internationalisation of European universities is now an unquestionable fact, at least for the mobility and the internationalisation of studies with the aim of finding points of confluence and intersectionality, which address common issues to rethink their impact and reshape the theoretical and political debate from multiple viewpoints. Moreover, both the internationalisation and globalisation of Higher Education oblige institutions to tackle many new challenges, including the internationalisation of knowledge and means, which need to avoid the risks of imposing a homogeneous knowledge and an erasure of differences and ideological conflicts. These processes form the background to frame a manifold mobility programs that involve teaching, research by staff and students, as well as the internationalisation of the research agendas of institutions. 


\section{Irish Studies towards the future}

ABEI and the W. B. Yeats Chair of Irish Studies have fostered since 2000s a circular academic globalization involving universities, centres and associations from different countries in multiple interdependence (Canclini's concept of globalization, 1999); but, which institutions are able to revert local knowledge to the Irish world and bring the global Irish knowledge back to the local and to our society?

European scholars and university administrators used to promote an institutional internationalization supporting symmetrical academic exchanges for the construction of a complementary global knowledge through research networks. However, South America has not received a positive double-way signal to gain a visible academic space in those countries. The majority of them does not accept the idea of signing asymmetrical agreements because institutions in Asia or Latin America are not highly qualified in the university world rankings and will not improve the ranking of their institutions. Therefore, which are the strategies that Irish Studies scholars adopt to resist this global trend? Are these strategies successful enough to establish a double-way exchange without depending on individual scholars as it is happening now? How can South American universities become more institutional and transnational?

In Brazil, the collaboration with Irish universities has been an important component of international strategic aims. In the last decades, the University of São Paulo has strengthened significant partnerships with Trinity College Dublin, Limerick University, University College Cork, NUI Maynooth, University College Dublin, where an agreement included the development of a project on Brazilian-Portuguese language teaching, and more recently with NUI Galway, due to the generous support of Irish colleagues that have been at USP and participated in the co-supervision of our postgraduate students' research. Not less important are the links with Irish Studies Associations such as AEDEI, IASIL and SILAS, among others mentioned above. But will this first stage of co-operation be continued in the future by other colleagues of the affiliated institutions?

Links are based on personal contacts and research affinities. However, it is important to have a strategy to build up an institutional continuity independently of these personal links. In non-English speaking countries, strategies are essential above all. I hereby suggest five actions that would allow the institutionalisation of Irish studies in a double-way sustainability:

- Promotion of multilateral alliances with international projects that enhance interdisciplinarity. Thematic projects of research and teaching, including of the language of the partner country, will generate agreements, which will create a multilateral educational impact.

- The creation of double-degree courses (in undergraduate and postgraduate levels), which are complementary, or rather supplementary, will result in joint-publications and the consolidation of an intercultural and transnational knowledge.

- Transnational online and hybrid courses will allow postgraduates to create their own networks through joint research and double-way teaching internships in the partner institution to share the results of their research and co-supervision by specialists of the host institution.

- Transdisciplinary integration is also a challenge to be part of the institutional Irish Studies strategies. A dialogue between disciplines of hard sciences and technology with social sciences and other disciplines of Humanities would open the way to new fields of research with the inclusion of Irish-Latin American knowledge -a transformation of Higher Education research in STEM into STEAM (Science, Technology, Engineering, Arts and Mathematics). 
- The creation of stronger links between the embassies and consulate-generals of partner countries with Ireland and vice-versa, to renew the Reader Programmes abroad or support Departments or Centre of Studies of their own country at the partner university; for example, the Department of Spanish, Portuguese and Latin American Studies at University College Cork. It could also be a Centre of Irish-Latin American Studies at any Irish university, which could complement the Irish curricula and offer itinerary courses and events to other Irish universities, supported by a pool of Latin American governments' embassies.

These double-way actions could sound rather utopian, but I would advocate that we should have transgressive utopian thoughts to move the wheel of innovative alternatives for Irish Studies to achieve the aim of an independent institutionalisation and play the role of a protagonist in the global and multilateral agenda of higher education.

To conclude, a comprehensive internationalization is an active commitment "to infuse international and comparative perspectives throughout the teaching, research, and service missions of higher education. It shapes institutional ethos and values and touches the entire higher education enterprise" (Hudzik 2011). ${ }^{9}$ If we apply a comprehensive internationalization strategy to Irish Studies research networks or Alliances we will be able to counterbalance the risks of academic globalization with the reconfiguration of an educational system that will be on alert to undermine the totalising power of global forces on local life. Irish Studies should remain open to global interactions in research, teaching, and staff and student mobility, in multiple directions, in order to increase close academic relationships with other Centres and Chairs within Ireland and beyond its borders, to achieve an academic network of multilateral dimensions.

International partners are key to create a comprehensive academic environment. The growing physical presence of scholars developing Irish Studies at USP with the hope of attending joint courses with partner institutions and (still an unrealized aspiration) to have the opportunity of achieving a joint degree with an Irish university in the near future, reveal both a great effort to improve English proficiency and a rising curiosity towards the Irish language and culture in the various fields of research. The increase of articles accepted by joint publications represent an important recognition of the quality of knowledge production in non-English speaking countries.

We should also be completely committed to working not only with other universities but also with national and international bodies to do all we can to ensure continued transnational interaction as fully as possible in the challenging times ahead. We can follow Hans De Wit's (2015) suggestion to consider the importance of an "intentional process of integrating an international, intercultural or global dimension into the purpose and functions" of our institutions to be able to work with the increasing diversity of challenges that an Irish Studies professional also has to face: "to make a meaningful contribution to society". 10 If we want to create a self-sustained global field of Irish Studies we have to consolidate an international academic environment in our institutions capable of creating human resources, plural and highly qualified Higher Education population and research that will make the difference in the transnational and global world of today.

\section{Notes}

${ }^{1}$ The exception is Patrick O'Sullivan's edition of the first volume of the series The Irish World Wide, Patterns of Migration (London: Leicester University Press, 1992), which includes Patrick McKenna's article "Irish Migration to Argentina" (63-83). 
${ }^{2}$ Among the revolutionary leaders were the Irish-born Argentine Admiral William Brown, the Chilean great liberator Bernardo O’Higgins, the Venezuelan general Daniel Florence O’Leary, Francis Burdett O’Connor, John Thomond O'Brien who fought for the independence of four republics on the South American continent (Argentina, Chile, Peru and Bolivia). See Tim Fanning, Paisanos. The Forgotten Irish Who Changed the Face of Latin America (Dublin: Gill Books, 2016).

${ }^{3}$ See the Brazilian trajectory of Irish Studies in the introductions to Irish Studies in Brazil (São Paulo: Humanitas, 2005), A New Ireland in Brazil (São Paulo: Humanitas, 2008) and more recently in the ABEI Journal 21.2, which celebrates 30 years of the Brazilian Association of Irish Studies and 10 years of the WB Yeats Chair of Irish Studies at USP. http://revistas.fflch.usp.br/abei/issue/view/255.

${ }^{4}$ See Juan José Delaney’s Borges and Irish Writing (Buenos Aires: Embajada da Irlanda, 2018).

5 The books by Thomas Murray, The Story of the Irish in Argentina, published in 1919, Eduardo Coghlan's genealogical study, Fundadores de la Segunda Época: los Irlandeses (1967) and Juan Carlos Korol e Hilda Sábato, Como fue la inmigración irlandesa en Argentina (1981) are the most cited sources when Patrick McKenna (1992), the journalist Andrew Graham-Yool (1981), Laura Izarra (1994, 2002, 2010, 2018), Edmundo Murray (2005), Tim Fanning (2016) and Dermot Keogh (2016) reconstruct the history and literature of the Irish community in Argentina. In Brazil, Fernando Basto (1971) writes about the Irish mercenaries in Taperoá, Miguel Alexandre de Araújo Neto (2003) writes on the Anglo-Brazilian Times, Oliver Marshall publishes an extensive research in English, Irish and Irish-American Pioneer Settlers in Nineteenth-Century Brazil (Oxford: University of Oxford, 2005), Angus Mitchell on Roger Casement in the Amazon (1997, 2003) and Laura Izarra's Narrativas de la diáspora irlandesa bajo la Cruz del Sur (Buenos Aires: Corregidor, 2010). It must be highlighted Michael Lillis and Ronan Fanning's Eliza Lynch: Queen of Paraguay (2009), the biography of Eliza Lynch before and after the death of her partner, the dictator Francisco Solano López, and Paraguay's war against the Triple Alliance (Brazil, Argentina and Uruguay). The Irish film director Alan Gilsenan directed a documentary drama (2013) on Irish-born Eliza Lynch based on the biography.

6 The Anglo-Brazilian Times (1865-1884), The Southern Cross (1875-ongoing), The Standard (1861-1959), Fianna (1910-1912), The Irish Argentine (1888-1889). Many sketches, short stories and poems of Irish and diasporic writers were published in those newspapers revealing the different cultural, ideological and political aims of their editors.

${ }^{7}$ The SPeCTReSS research network has a double-way mobility of 31 experienced and early researchers from nine leading universities https://spectressnetwork.wordpress.com/about/. The GHI network has a double-way mobility of 14 scholars https://www.tcd.ie/trinitylongroomhub/media/news/articles/2018-08-03-CHCI.php

${ }^{8}$ https://crisesofdemocracy.home.blog/syllabus/.

9 John K. Hudzik in Comprehensive Internationalization: From Concept to Action (NAFSA: Washington, DC, 2011).

${ }^{10}$ In April 2015 Hans De Wit proposed a new definition of internationalization: "The intentional process of integrating an international, intercultural or global dimension into the purpose, functions and delivery of postsecondary education, in order to enhance the quality of education and research for all students and staff, and to make a meaningful contribution to society” (De Wit, INQAAHE conference, Chicago, U.S., 2015).

\section{Works Cited}

Araújo Neto, Miguel Alexandre de. "Imagery and Arguments Pertaining to the Issue of Free Immigration in the Anglo-Irish Press in Rio de Janeiro". ABEI Journal 5 (June 2003): 111-27.

Basto, Fernando L. B. Ex-Combatentes Irlandeses em Taperoá. Rio de Janeiro: Vozes, 1971.

Bulfin, William. Rambles in Eirinn. Dublin: M.H.Gill and Son, 1929.

Canclini, Néstor García. La globalización imaginada. Buenos Aires: Paidós, 1999.

Coghlan, Eduardo. Fundadores de la segunda época: los irlandeses. Buenos Aires: [Publisher not identified], 1967.

Eyerman, Ron. "Intellectuals and Cultural Trauma". European Journal of Social Theory. London, 14.4 (2011): 453-67.

Fanning, Tim. Paisanos. The Forgotten Irish Who Changed The Face of Latin America. Dublin: Gill Books, 2016.

Graham-Yooll, Andrew. La colonia olvidada. Tres siglos de presencia británica en la Argentina. Buenos Aires: Emecé Editores, 2000. 
Izarra, Laura and James Silas Rogers. "Life Writing and Diaspora I: The Autobiography of The Irish in The USA and Latin America". A History of Irish Autobiography. Ed. Liam Harte. Cambridge, UK: Cambridge University Press, 2018. 315-30

Izarra, Laura. Narrativas de la diáspora irlandesa bajo la Cruz del Sur. Buenos Aires: Corregidor, 2010. . "The Irish under The Southern Cross". Crop No.1 (November 1994): 50-4.

. "Irish Diasporic Voices in South American Border Narratives". ABEI Journal 3 (June 2001): 137-50.

. "The Irish Diaspora in Argentina". British Association for Irish Studies Newsletter 32 (October 2002): 5-9.

Keogh, Dermot. Twentieth Century Ireland. Dublin: Gill and Mcmillan, 1994, 2005. . La independencia de Irlanda: la conexión argentina. Buenos Aires: Universidad del Salvador, 2016.

Kiberd, Declan. Inventing Ireland. The Literature of The Modern Nation. Cambridge, Massachusetts: Harvard University Press, 1995.

Korol, Juan Carlos and Hilda Sábato. Cómo fue la inmigración irlandesa en Argentina. Buenos Aires: Editorial Plus Ultra, 1981.

Lillis, Michael and Ronan Fanning. Calúnia. Elisa Lynch e a Guerra do Paraguai. São Paulo: Editora Terceiro Nome, 2009.

Mitchell, Angus. The Amazon Journal of Roger Casement. Dublin: Lilliput Press, 1997. . Sir Roger Casement's Heart of Darkness: The 1911 Documents. Dublin: Irish Manuscripts Commission, 2003.

McKenna, Patrick. (1992) "Irish Migration to Argentina". The Irish World Wide. History, Heritage, Identity. Vol. 1 Patterns of Migration. Ed. Patrick O'Sullivan. London and Washington: Leicester University Press, 1997, 63-83.

Murray, Edmundo. Devenir irlandés. Narrativas íntimas de la emigración irlandesa a la Argentina (1844-1912). Buenos Aires: Eudeba, 2004.

Murray, Thomas. The Story of the Irish in Argentina. Buenos Aires: Corregidor and Cork University Press, 2012.

Teichler, Ulrich. "The Changing Debate of Internationalisation of Higher Education." Higher Education. 48.1 (2004): 5-26.

Laura P. Z. Izarra is Full Professor of Literatures in English at the University of São Paulo, coordinator of the W.B.Yeats Chair of Irish Studies/USP and former president of the Brazilian Association of Irish Studies-ABEI (2009-2018). She is the author of Mirrors and Holographic Labyrinths. The Process of a 'New' Aesthetic Synthesis in the Novels of John Banville (New York, 1999), Narrativas de la diáspora irlandesa bajo la Cruz del Sur (Buenos Aires, 2010) and O Trauma Cultural. Ressonâncias literárias irlandesas (São Paulo, 2020). She has published widely on Irish contemporary literature and is editor and co-editor of many books and of ABEI Journal. At present, her main research interests are literature of the diaspora, cultural trauma and memory studies.

lizarra@usp.br 